\title{
Conceptualizing Organizational Effectiveness in Light of Islamic Value System
}

\author{
Amal Hayati Ishak, Muhamad Rahimi Osman, and Ghafarullahhuddin Din
}

\begin{abstract}
The linkage between organizational culture and organizational effectiveness has been elaborated by some empirical studies. Yet, organizational culture which includes shared values, philosophy, rules and habits are found to be varied across different continents, race, belief and others. However, little reference has been made to relate organizational culture with religion, specifically, the religion of Islam. So far, instruments developed and employed are also found lacking with religion influence which is somehow crucial in certain countries. This article conceptualizes organizational effectiveness in light of Islamic value system. Prior to that, the article elaborates the concept of organizational culture and organizational effectiveness, before elaborating on the linkage between the two. Consequently, the uniqueness of Islamic value system is explained as it may act as a motivation towards values adherence in organizational context. Finally, some suggestions for future research are also included in this article.
\end{abstract}

Index Terms-Organizational culture, organizational effectiveness, Islamic value system.

\section{INTRODUCTION}

There is an underlying assumption of direct relation between organizational culture and organizational effectiveness. The assumption is supported by some empirical studies [1]-[3]. These studies are done in limited geographical area with limited cultural traits. Thus generalization of organizational culture remains questionable as cultures are unique depending on its locality or historical background of a country which forms the culture of the nation. And there are other factors which differentiate organizational culture from one another. These limitation warranted more studies to be conducted at different locality, involving different inherent culture and belief. This paper suggests integration of Islamic value system in conceptualizing organizational culture and organizational effectiveness. This may provide a solution towards generalized theory of organizational culture limited to an Islamic setting.

\section{ORgANiZATIONAL CULTURE}

Organizational culture has been initiated by Hofstede and

Manuscript received May 24, 2013; revised July 22, 2013.

The authors are with the Academy of Contemporary Islamic Studies (ACIS), Universiti Teknologi MARA Shah Alam, Selangor, Malaysia (e-mail: amalhayati@salam.uitm.edu.my/amal_ishak@yahoo.co, mrahimi313@salam.uitm.edu.my,ghafarullahhuddin@salam.uitm.edu.my).
Schein in the 1980s [4]. Although they may be different definition of organizational culture, there seem to be a consensus pattern of shared practices, values, beliefs, expressive symbols and norms. According to Hellriegel, Slocum and Woodman [5], organizational culture represents a complex pattern of beliefs, expectations, ideas, values, attitudes and behaviors shared by organizational members.

Martin [6] describes six organizational cultures: 1. Routine behaviors such as organizational rituals, ceremonies, interaction or language spoken throughout the organization; 2. Certain norms shared by organizational members such as “a fair day's work for a fair day's pay; 3. Dominant values such as "product quality"; 4. Philosophy guiding organizational policies; 5. Rules that create sense of belonging; 6. Feeling or climate represented by the physical layout. Schein [7] further adds embedded skills, habits, shared meanings, rituals and celebrations. Since there is a long list of organizational culture, this study focuses on values which refer to the publicly announced and accepted values that are collectively pursued by organizational members [8].

Schein [7] claims that culture has powerful impact, yet invisible and considerably unconscious. It is the hidden and complex aspects of individuals, organizations and occupations, which appear to be mysterious. It is the rationale of attitudes and visible behaviors. This explain why culture need to be understood. Prajogo \& McDermott [4] claim that the rationale of understanding culture is because it allows managers to create an organizational shared culture, or work environment, compatible for their chosen strategic missions. For instance, if quality product is the mission, the culture of teamwork in quality assurance will be necessary. In the literature, culture has been studied in two major focus; its content and practice. The first refers to types of values and behavior held by organizational members and the latter is the depth and breadth of the behaviors [4].

\section{ORGANIZATIONAL EFFECTIVENESS}

Organizational effectiveness is used interchangeably with organizational performance simply referring to how well an organization is doing. Hence, it is also referred to as organizational performance. Various indicators or measurements have been used in organizational effectiveness studies such as productivity, profit, growth, turnover, product quality and innovation, employee satisfaction or employee work attitude. These indicators may generally be divided into financial and non-financial according to the context under study. Similarly, literatures also have agreed on the dearth of 
consensus in indicators of organizational effectiveness [2], [4].

\section{LinKING ORganizational CULTURE AND ORGANIZATIONAL EFFECTIVENESS}

Denison \& Mishra [1] assert that relationship between culture and organizations have gain interest since 1930s. Sociologists, social anthropologists and social psychologists have integrated culture in the functions of society and organizations, such as Weber [9] and Radcliffe-Brown [10]. These scholars emphasized on the importance of culture in the process of adaptation, occured in organizations. They viewed culture as a behavior pattern which is conveyed socially and relates man to their environment [1].

Since 1980s, studies regarding to organizational culture is increasing [11]. It is used to explain the phenomenon of economic performance of Japanese over American firms. The different culture of the Japanese has been referred to as the rationale of their success [12], [13]. Presented in Table I is the difference between Japanese and American value system.

TABLE I: VALUE SySTEM OF THE JAPANESE AND AMERICAN

\begin{tabular}{lll}
\hline Factor & Japan & America \\
\hline Key strategy & Paternalism & Entrepreneurship \\
\hline People & Homogenous & Heterogenous \\
\hline Basic concern & People & Tasks \\
\hline Orientation & $\begin{array}{l}\text { Group and } \\
\text { harmony }\end{array}$ & Individual \\
\hline Social system & Close and rigid & Open and fluid \\
\hline Family & Extended & Nuclear \\
\hline Education & Specialized & Liberal \\
\hline $\begin{array}{l}\text { Employee's } \\
\text { feeling about firm }\end{array}$ & Oneness with firm & $\begin{array}{l}\text { A place to earn } \\
\text { money }\end{array}$ \\
\hline
\end{tabular}

Source: Crocker, Charney \& Chin [14].

For example, in the area of quality management, it was the American quality gurus that had handed over the knowledge to the Japanese to overcome their devastation state after the defeat in World War II. Deming and Juran are both invited to Japan to lecture on quality management in the 1950s [15]. Even the Japanese quality award is named the Deming Prize symbolizing the origin of quality management and the Japanese gratefulness to the Americans in the knowledge dissemination process. Nevertheless, they succeeded in surpassing the Americans due to their cultural values [13], [16]. Khaliq \& Shamim [13] assert that they do not become "Americanized" or "westernized" in the process, but they successfully did it on their own beliefs and values. The Japanese experience has indeed, proven the influence of culture in organizational effectiveness.

Fey \& Denison [2] argue that there is a dearth of generalized theory in the linkage of organizational culture and effectiveness. They also explain that this is subject to the complexity of culture and its questionable measurements. However, Denison \& Mishra [1] suggest a solution with the Denison Organizational Culture Model (DOCM) which is a measurement model equipped with measurement tool of organizational effectiveness based on four cultural traits of involvement, consistency, adaptability and mission. The model claims that effective organizations will yield high levels of these cultural traits. The DOCM which is grounded in empirical studies, have been suggested by Casida [11] to be employed in linking organizational culture to organizational effectiveness in a nursing unit. Nevertheless, the DOCM have some limitations. With only four cultural traits, it may be incomprehensive to be generalized. It also may be too narrow and does not provide in-depth measures. Fey \& Denison [2] apply the American model in Russian context. They discovered some cultural dynamics are ignored by the model which originates form the difference in the country's historical Communist background. Theoretically, this is parallel with Hofstede's [17] claim that western based instrument is incomprehensive and inappropriate for a non-western setting. Therefore, a more universal and general measure is warranted [2], [3].

Despite lack of generalized theory linking organizational culture and effectiveness, some empirical studies support the link [2], [3]. In a more recent study, Cameron et.al [3] state that there is an increasing trend to study the relationship of organizational good practices and organizational effectiveness. Good practices are a subset to organizational culture. However, their study which has been conducted among employees of a health care sector may not include good practices applied in other different sectors. However, the study reveals that good values influence and able to predict organizational effectiveness. On the other hand, values may indirectly affect organizational effectiveness by creating a more effective environment [18]. These are among the studies which are in consensus regarding the importance of values in organizational effectiveness.

\section{Definition AND Theory of VAlue}

Values and ethics are two main ingredients in the success of management process. Values and ethics are commonly used interchangeably [19], [20] and are sometimes found to be used together in writings. Philosophers define ethics as the knowledge, science or discipline which investigate good (right act) and evil (wrong act) in behavior within the capacity of man's intellect [21]. This is agreed by Pojman [22], referring ethics to the overall broad philosophy of human conduct. Ethics is also seen as a code of moral conduct [23], [24] as regulated among today's organization.

The concept of value have a long history in the area of psychology, sociology, anthropology, political science, economics and other fields of social research. Since the 1960 s, the term "values" is used across various disciplines including sociology, psychology, philosophy, political science as well as management [25].

Rokeach [26] defines values as "abstract ideals, positive or negative, not tied to any specific object or situation, representing a person's beliefs about modes of conduct". The definition relates values as determinants of behavior and has grounded future studies on human values [25].

Rokeach [27], in explaining the concept of value, have anticipated that value is the core concept across all the social science discipline. As Rokeach is a renowned psychologist, the theory have largely contributed and influenced future related studies [28], [29]. He published three consecutive 
books in elaborating the concept of value. The first, "Beliefs, Attitudes and Values: A Theory of Organization and Change" (published in 1969), explained the philosophy of value, its importance and association to psychological aspects of beliefs and attitudes. In the second book, "The Nature of Human Values" (published in 1973), he explained the theory of value and introduced Rokeach Value Survey (RVS) which is an instrument to assess values. The third book, "Understanding Human Values" (published in 1979), further discusses the validity of RVS using various studies which employ the instrument [28].

Rokeach [27] states that values are centrally located within one's total belief system informing a person how he should behave. It determines, influences and justifies one's action and attitude. Therefore, values should have a significant impact even in the absence of some motivational variables, for example incentive and job scope. Furthermore, he adds that a value, once internalized, becomes a standard or yardstick which guides actions, attitudes, comparisons, evaluations and justifications [28], [29].

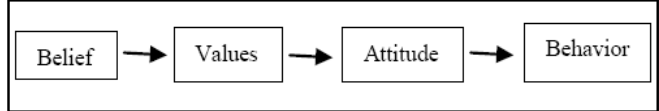

Fig. 1. Illustration of linkages between beliefs, values, attitudes and behavior.

Rokeach [26] differentiates between beliefs, values, attitudes and behavior Summarizing the differences, beliefs are predisposition to action and values are the cognitive rationale for attitudes. On the other hand, attitude is orientation towards object or situation, resulted from application of values. Behaviour is the real situation which illustrates the value which one holds on to. Fig. 1 explains the simple relation of belief, values, attitude and behavior.

TABLE II: ROKEACH'S [27] TERMINAL AND INSTRUMENTAL VALUES

\begin{tabular}{|l|l|}
\hline Terminal values & Instrumental values \\
\hline A comfortable life & Ambitious \\
\hline An exciting life & Broadminded \\
\hline A sense of accomplishment & Capable \\
\hline A world at peace & Cheerful \\
\hline A world of beauty & Clean \\
\hline Equality & Courageous \\
\hline Family security & Forgiving \\
\hline Freedom & Helpful \\
\hline Happiness & Honest \\
\hline Interharmony & Imaginative \\
\hline Mature love & Independent \\
\hline Natural security & Intellectual \\
\hline Pleasure & Logical \\
\hline Salvation & Loving \\
\hline Self-respect & Obedient \\
\hline Social recognition & Polite \\
\hline True friendship & Responsible \\
\hline Wisdom & Self-controlled \\
\hline
\end{tabular}

Source: Rokeach [27].

Hitlin [25] advocates RVS as the original empirical work on values measurement which have largely grounded future studies. The RVS was developed based on interview with groups of students. The instrument identified 36 values, equally divided into instrumental and terminal values. Terminal values are end-state of existence that a person strives to achieve, for instance, comfort and wisdom. Instrumental values are modes of behavior, for instance, honesty and helpfulness, which are behaviors that facilitate the attainment of terminal values. The values (presented in Table II) listed the values in alphabetical order. RVS uses a ranking system requiring respondents to rank the values from one for the most important, to 18 for the least important.

The RVS have been criticized for too vague and not specific. Apart from that, the ranking system of measurement is said to be burdensome for respondents as one might not be able to select a value prior to another as some of the values may be of the same importance, thus producing less reliable results [25], [28]. With the critiques on RVS, there may be an opportunity to suggest values based on religion, especially with regards to Islam as the official religion in Malaysian context.

\section{ISLAMIC VALUE SYSTEM}

In Islam, ethics and values belongs to the discipline of akhlaq [24], [30]. Indeed, values are popularized with the term akhlaq in Islam. According to Imam Ghazali in his great treatise, Ihya' Ulumuddin, akhlaq is categorized as fardhu 'ain and hence, compulsory to learn [30].

Akhlaq literally comes from an Arabic word, "khuluq" which means natural habit, custom, behavior or lifestyle of an individual or community. Technically, akhlaq means natural habit or behavior including habit acquired through training or education. The discipline of akhlaq is define as the knowledge of determining good and evil, what should be done, what should be the aim and how it should be done in accordance to revelation, the nature of man and his intellect [24].

According to Miskawayh (died 1030), a pioneer of Islamic morality, akhlaq is a state of soul or disposition formed in man's soul which directs a person to behave. Inspired by Miskawayh, Al-Ghazali (died 1111), define akhlaq as strong disposition in man's soul producing behavior without difficulties of thinking and deliberation. In other words, akhlak is the character which is innate (naturally) in the heart and simply arise from it actions without consideration. Two major points of Al-Ghazali's definition is the constant stability of desire to behave and spontaneous behavior. Later Islamic moralists, Fakhru al-Din al-Razi (died 925), Nasir al-Din al-Tusi (died 1274) and al-Dawwani (died 1502) agreed with the definition. Therefore, akhlaq can be concluded as the underlying reason of behavior, comes naturally and spontaneously. If a person have good values, then he is well-behaved, in contrast, if a person have negative values, then he is ill-behaved [24].

Akhlaq can be divided into akhlaq mahmudah and akhlaq mazmumah, which is similar to positive values and negative values. There are two criteria in distinguishing akhlaq mahmudah and akhlaq mazmumah, which is the shariah, and intellectual capacity of man. Each commandment of the shariah (from primary sources of Islam) is good and each 
prohibition is evil. The acceptance of certain act by man's intellect can be considered as good, even there are no underlying evidences from the shariah [24].

In Islam, akhlaq is very crucial and must be applied in every deed of a man. It is the foundation of every discipline, not merely a part of it. This is because, any work done diligently will be blessed and produce good results. As an analogy, a worship (ibadah) performed with sincerity (ikhlas) and (focus) khusyu' will be accepted and rewarded, but a worship performed with pride (riya') is worthless [24].

In a nutshell, ethics and values are words in the discipline of human conduct. However, they are slightly different from each other. Ethics is a philosophy or theory regarding human conduct, often regulated and formally executed as code of conducts. The human conduct which comprises right and wrong acts are the values, commonly written as positive and negative values [21], [24]. Another point of difference is ethics originates from human's mind, whereas akhlaq originate from religion [21]. That is why in Islam, ethics and values are discussed under akhlaq which is obligatory subject to learn by every Muslim.

Value system is a set of preferred ethics based on individual or society judgement, comprises of positive and negative values [12], [31], [32]. Nik Azis [31] further suggests a faith based value system as the modern western civilization have ignored the influence of religion in their ethical issues [12], [30]. This article will respond on the faith-based approach.

Alhabshi [12] in explaining his idea of Islamic value based management, define Islamic value system as the preferred values and manners originate from the shariah. The foundation is the belief system (tauhid), and the source is the revelation. Therefore, values are closely related to belief, feeling, emotion, tradition and pride. He also points that values may be naturally innate, emulated, nurtured or forced. He further elaborates that positive values will resulted in positive results such as improved relationship, respect, performance and reduced stress. Since values instruct a person's feelings and actions, he considers values as the 'moral navigational devices'.

Similarly, Jabir [32] explains that Islamic values system is a collection of akhlaq which mould excellent Muslim characters that are capable of contributing to the society, cooperate and strive for the well-being of individual, family and religion. He states that the basic foundation of values in Islam is active quest of knowledge, as prevalent in the first revelation, which is Surah al-Alaq, verse 1-5. The core information valued in the first revelation is the importance of knowledge and both reading and writing as method of acquiring knowledge.

\section{The UniQueness OF ISLAMiC VALUE SYSTEM}

In Islamic value system, iman (faith) and taqwa (piety) are the foundations which direct Muslims towards the right path in a rightful manner [12], [30]. Alhabshi [12] further states that both faith and piety have influence on the behavior and character of an individual. Character is the state of soul which produces consistent and spontaneous physical actions. If the soul is pure, it will produce pure character consistently. In contrast, if the soul is impure, the character will be evil and bad. For instance, the value of brotherhood and unity will discourage a Muslim from inflicting harm towards others, and the value of responsibility will encourage a person to perform his duties well. Furthermore, the foundation of tauhid (oneness of God) is capable of providing a strong abstaining and enforcing authority to observe ethical attitudes [12], [33]. Tauhid includes the belief in eternal next life which is one of the pillars of faith.

In Islam, ethics and values are akhlaq which uses the revelation as a standard to determine good and evil. On the other hand, the modern value system is based on previous inherited belief of the society and evolution of man and the surrounding. Hence, it does not guarantee man are protected from bad deeds as quoted by Bauman [23];

"After all, they all tell us how to approach people within our sight and reach, and how to decide which actions are good (and thus ought to be taken) and which are bad (and thus ought to be avoided), depending on their visible and predictable effects on such people. Even if we abide by such rules, it is far from certain that disastrous consequences will be avoided."

In Islam, shariah distinguishes positive values from negative values. Shariah refers to the laws and regulation revealed by Allah to his Messenger, Prophet Muhammad SAW [34]. Good values are made obligatory (wajib) and recommended (sunat) and will be rewarded, whereas bad values are prohibited (haram) and subject to punishment. Therefore, the shariah provides a standard of guidance for Muslims' behavior. The reward and punishment is the enforcer for the Muslims to apply the values. However, in western theory of value, the standards of positive or negative values are established based on human judgments [21], [24], [30]. Such basis of determination is not universal and difficult since every person may have different interpretation [21]. Nevertheless, Islam offers a systematic set of law comprises of the primary sources, the Quran and hadith, and secondary sources including the ijtihad and ijma'of the ulama' (the consensus of Islamic scholars) and 'uruf (customary practice which does not contradict with the shariah), for a reference source [30].

Islamic value system is certain and fixed regardless of time, place and culture. This means what considered as bad today, will never be considered as good in the future. In contrast, modern value system determines positive or negative values based on society's acceptance. Thus the values are not universal, and may differ between societies or change over time and space [12], [30]. Alhabshi [12] added, as an example, modern societies have been paving way towards liberalism and homosexual in the name of freedom and individual right. This reflects the changing of values due to changes in the society's belief over time. In secular societies, values are not affected by the religion, thus changes in values are allowed. In contrast, values underpin with religion is firm and sustainable. In Islamic value system, these elements remain prohibited as stated by Quranic injunctions (primary source in Islam) and will never be modified. For example, a simple act of lying is prohibited and will never be considered acceptable no matter what the rationale is. Maqbouleh [35] further adds that in order to preserve the permanent values, 
self-control is important to ensure a person would not transgress. The self-control is actually the fruit of iman and piety, which is the foundation of akhlaq.

Islamic value system enforces effectively through the system of Islamic legal rulings, which refers to wajib, sunat, harus, makruh dan haram. Understanding this will ensure conformance of the values leading to a peaceful and harmony society. For example, the culture among the Malaysian Malays society to bend down the body while walking in front of the elders as a sign of respect is considered permissible, somehow encouraged, as it can create a harmonious culture and environment [30]. Table III below explains effect of Islamic legal rulings on value system.

TABLE III: EXPLANATION ON ISLAMIC LEGAL RULINGS

\begin{tabular}{|l|l|l|}
\hline Hukum & Explanation & $\begin{array}{l}\text { Effect on Islamic Value } \\
\text { System }\end{array}$ \\
\hline Wajib & $\begin{array}{l}\text { Obligatory to do } \\
\text { Sinned if left }\end{array}$ & $\begin{array}{l}\text { A person will perform the } \\
\text { values with faith and piety } \\
\text { even it is not regulated in } \\
\text { the organization or not } \\
\text { within working hours or not } \\
\text { within the organization }\end{array}$ \\
\hline Sunat & $\begin{array}{l}\text { Encouraged to do } \\
\text { Not sinned if left }\end{array}$ & $\begin{array}{l}\text { A person will perform for } \\
\text { Allah's blessings and } \\
\text { rewards voluntarily }\end{array}$ \\
\hline Harus & $\begin{array}{l}\text { Permissible either to } \\
\text { d or leave }\end{array}$ & $\begin{array}{l}\text { A person will aware that the } \\
\text { value is permissible in } \\
\text { Islam and it is optional }\end{array}$ \\
\hline Makruh & Encouraged to leave & $\begin{array}{l}\text { A person will be discourage } \\
\text { to perform eventhough it is } \\
\text { not a sin }\end{array}$ \\
\hline Haram & $\begin{array}{l}\text { Obligatory to leave } \\
\text { Sinned if done }\end{array}$ & $\begin{array}{l}\text { A person will avoid and } \\
\text { leave the deeds based on } \\
\text { faith and piety eventhough } \\
\text { it is not regulated }\end{array}$ \\
\hline
\end{tabular}

Source: Sharifah Hayaati [30]

There are two important consequences following the above system of legal rulings. First, the system positions the feelings of hope (raja') and fear (khauf) towards The Creator. Hope that Allah will strengthen the faith and spirit to fulfill all His command and prohibition, and fear to transgress the commands and prohibition of Allah. Both lead to obedience [30]. Second, the understanding of Islamic legal rulings will assist in realizing the values as a regulated code of ethics. This has been highlighted by al-Ghazzali, quoting that values inculcated in human soul can produce good deeds spontaneously. Another scholar in akhlaq, Ibn Manzur, agreed by saying akhlaq is a reflection of values arising from man's inner self based on obedience towards the shariah [30].

Furthermore, Islamic values permeate all spheres of human's life [33], [36]. Therefore it symbolizes a holistic concept of positive values and its adaptability within the system of legal rulings in all facets of life. For instance, in quality management, Islamic values are believed capable of creating a conducive work environment [19].

\section{THE Proposed FrameWORK}

Combining the theory of value and the suggested linkage between organizational culture and organizational effectiveness, this article suggests; 1. Islamic value system, rooted in Islamic belief system should be internalized in organizational culture, 2. Attitude and behavior which arises from value system, may reflect non-financial organizational effectiveness. However, both is not definite and may be replaced with other organizational effectiveness indicators depending on the context under study. Thus, Fig. 2 below presents the conceptualization of these concepts;

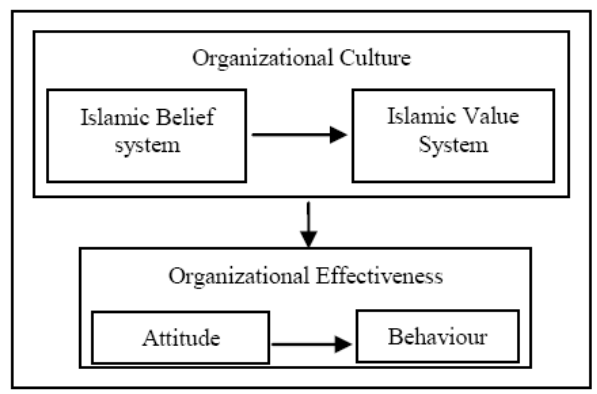

Fig. 2. Proposed conceptual framework.

The strength of the above framework lies in its belief system which is a firm force towards compliance of the values [30], [35]. A person, who holds firmly to its belief system, will naturally be inclined towards conformance in all commands and prohibitions. Consequently, the applications of values may create a conducive work environment [33] and organizational effectiveness [18]. Nevertheless, the above framework calls for further empirical studies. Interestingly, the model also may lead to a generalized concept, however, limited for an Islamic setting, as all Muslims are oblige to uphold to the same belief system and are bound to the same rulings system.

\section{CONCLUSION AND Future RESEARCH AGENDA}

Organizational culture influences and may predict organizational effectiveness. These have been supported by some empirical studies. However, these studies have made little reference to religion. Similarly, instruments developed and employed are mainly based on existing empirical literatures with little reference to religion. Acknowledging the gaps, this article proposes a conceptual framework of organizational effectiveness in light of Islamic value system. The proposed framework warranted further scientific research. Hence, there are two suggestions for future research; first is the development of appropriate instrument and second, empirical studies to approve the suggested framework. Both suggestions come in sequence, which means, an appropriate and validated instrument is needed prior to the execution of empirical study.

\section{REFERENCES}

[1] D. R. Denison and A. K. Mishra, "Toward a theory of organizational culture and effectiveness," Organizational Science, vol. 6, no. 2, pp. 204-223, 1995.

[2] C. F. Fey and D. R. Denison, "Organizational culture and effectiveness: can American theory be applied in Russia?" Organization Science, vol. 14, no. 6, pp. 686-706, 2003.

[3] K. Cameron, C. Mora, T. Leutscher, and M. M. Calarco, "Effects of positive practices on organizational effectiveness," The Journal of Applied Behavioral Science, vol. 47, no. 3, pp. 266-308, 2011.

[4] D. I. Prajogo and C. M. McDermott, "The relationship between multidimensional organizational culture and performance," International Journal of Operations \& Production Management, vol. 31, no. 7, pp. 712-735, 2011. 
[5] D. Hellriegel and J. M. Slocum, Organizational Behaviour, USA: South Western College Publishing, 2001.

[6] J. Martin, Cultures in Organizations, New York: Oxford University Press, 1992.

[7] E. Schein, "The concept of organizational culture: Why bother?" in Classics of Organization Theory, 7th edition, J. M Shafritz, J. S Ott, J. S \& Y. S Jang, 2011, USA: Wadsworth Cencage Learning.

[8] T. E Deal and A. A. Kennedy, The New Corporate Cultures, New York: Perseus, 1999.

[9] M. Weber, The Protestant Ethic and the Spirit of Capitalism, Trans. by Talcott Parsons, New York: Scribers, 1930.

[10] A. R. Radcliffe-Brown, Structure and Function in Primitive Society, London: Cohen, 1952.

[11] J. Casida, "Linking nursing unit's culture to organizational effectiveness: A measurement tool," Nursing Economics, vol. 26, no. 2 , pp. 106-110. 2008 .

[12] S. O. Alhabshi, "Islamic values: Its universal nature and applicability," in Islamic Values and Management, eds Syed Othman Alhabshi and Aidit Haji Ghazali, Kuala Lumpur: IKIM, 1994.

[13] K. Ahmad and S. Ahmad, "Managerial Excellence-An Islamic Perspective," Malaysian Management Review, vol 29, no 4, December 1994, pp. 38-45

[14] O. L. Crocker, S. Charney and J. S. L Chin, Quality Circles a Guide to Participation and Productivity, Ontario: Methuen Publication, 1984.

[15] K. Ishikawa, What is Total Quality Control? The Japanese Way, translated by D. J. Lu, London: Prentice Hall, 1985.

[16] S. O. Alhabshi, "Quality and productivity conciousness: An Islamic approach," in Quality Management Islamic Perspectives, eds Khaliq Ahmad and Abulhasan M. Sadeq, Kuala Lumpur: Leeds Publications, 1996.

[17] G. Hofstede, Uncommon Sense about Organisations, London: Sage, 1994.

[18] D. Lozeau, A. Langley, and J. L. Dennis, "The corruption of managerial techniques by organizations," Human Relations, vol.55, no. 5, 2002, pp. 537-564.

[19] K. Ahmad, "Quality management: Islamic values and implications," in Ethics in Business and Management Islamic and Mainstream Approaches, eds Khaliq Ahmad \& Abulhasan M. Sadeq, London: ASEAN Academic Press, 2001.

[20] Sharifah Hayaati Syed Ismail al-Qudsy, "Values and ethics towards quality public delivery system of Malaysia," Journal Syariah, vol. 15, no. 2, 2007, pp. 25-43.

[21] H. Yaakub, Etika Islam Pokok-pokok Kuliah Ilmu Akhlaq, in Malay, Jakarta: CV Publicita, 1978.

[22] L. P. Pojman, Ethics, Amerika Syarikat: Wadsworth Publishing Company, 1999.

[23] Z. Bauman, Postmodern Ethics, Oxford: Blackwell Publishers, 1993.

[24] M. N. Omar, Falsafah Akhlaq, in Malay, Bangi: Penerbit UKM, 2010.

[25] S. Hitlin and J. A. Piliavin, "Values: Reviving a dormant concept," Annual Review of Sociology, vol. 30, 2004, pp. 359-393.
[26] M. Rokeach, The Nature of Human Values, New York: The Free Press, 1979.

[27] M. Rokeach, Understanding Human Values, New York: The Free Press, 1973.

[28] Y. Levy, Assessing the Value of E-Learning Systems, USA: Information Science Publishing, 2006.

[29] Z. Mahadi and H. Sino. "Hibungan Nilai Alam Sekitar dan Nilai Peribadi: Satu Analisa," (in Malay), Journal Pengajian Umum, Bil 7, 2006, pp. 1-12.

[30] Sharifah Hayaati Syed Ismail al-Qudsy, Etika Penjawat Awam dari Perspektif Islam, in Malay, Kuala Lumpur: Dewan Bahasa dan Pustak, 2010.

[31] N. A. N. Pa, "Kedinamikan pengertian nilai dalam penyelidikan dan pendidikan Matematik," in Malay, Masalah Pendidikan, vol. 31, no. 1, pp.59-75, 2008.

[32] J. Qamihah, Nilai-nilai Islam Satu Pengenalan, in Malay, trans. by Mudasir Rosder and Mohd Zawawi Abdullah, Kuala Lumpur: Bahagian Hal Ehwal Islam Jabatan Perdana Menteri, 1996.

[33] K. Ahmad, "Quality management foundation: an agenda for Islamization of management knowledge," Malaysian Management Review, vol.31, no.1, pp. 44-52, March 1996.

[34] A. A. B. Philips, The Evolution of Figh, Riyadh, Saudi Arabia: International Islamic Publishing House, 1995.

[35] M. M. Hammoudeh, Islamic Values and Management Practices, England: Gower Publishing Limited, 2012.

[36] Ali. Kettani, "Science and technology in Islam: The underlying value system," in The Touch of Midas Sciences, Values and Environment in Islam and the West, ed. Ziauddin Sardar, Selangor: Pelanduk Publications, 1988.

Amal Hayati Ishak was born in Perak, Malaysia, on August 1980. She receives a B. A in syariah and management (University of Malaya), MBA (Universiti Kebangsaan Malaysia) and is currently pursuing her PhD in Islamic management at academy of contemporary Islamic Studies (ACIS), Universiti Teknologi MARA (UiTM), Malaysia.

Muhamad Rahimi Osman was born in Terengganu, Malaysia, on November 1961. He receives a B.A in shariah and economics (University of Malaya), M.A in Shariah (Yarmouk University, Jordan) and PhD in Islamic banking and finance (International Islamic University Malaysia). $\mathrm{He}$ is currently a Professor cum the Dean of ACIS UiTM, Malaysia. He has published books related to Islamic Banking and Islamic Ethics.

Ghafarullahuddin Din was born in Kedah, Malaysia. He holds a $\mathrm{PhD}$ in Islamic Economics (University Sains Malaysia). He is an associate professor, and currently the head of Zakat, Sadaqah and Waqf Management Department, a unit vested under ACIS, UiTM. He has written books on Islamic Economics and Islamic Ethics. 